\title{
Growth and feeding ecology of coniform conodonts
}

\author{
Isabella Leonhard ${ }^{\text {Corresp., } 1}$, Bryan O Shirley ${ }^{2}$, Duncan J E Murdock ${ }^{3}$, John Repetski ${ }^{4}$, Emilia Jarochowska ${ }^{5}$ \\ ${ }^{1}$ Institute of Evolutionary Biology, University of Warsaw, Warszawa, Poland \\ 2 Paläoumwelt, Friedrich-Alexander Universität Erlangen-Nürnberg, Erlangen, Bavaria, Germany \\ 3 Oxford University Museum of Natural History, Oxford, United Kingdom \\ ${ }^{4}$ US Geological Survey-Emeritus, Reston, Virginia, United States of America \\ 5 Department of Earth Sciences, Utrecht University, Utrecht, Netherlands \\ Corresponding Author: Isabella Leonhard \\ Email address: isabella.leonhard@fau.de
}

Conodonts were the first vertebrates to develop mineralized dental tools, known as elements. Recent research suggests that conodonts were macrophagous predators and/or scavengers but we do not know how this feeding habit emerged in the earliest coniform conodonts, since most studies focus on the derived, 'complex' conodonts. Previous modelling of element position and mechanical properties indicate they were capable of food processing. A direct test would be provided through evidence of in vivo element crown tissue damage or through in vivo incorporated chemical proxies for a shift in their trophic position during ontogeny. Here we focus on coniform elements from two conodont taxa, the phylogenetically primitive Proconodontus muelleri Miller, 1969 from the late Cambrian and the more derived Panderodus equicostatus Rhodes, 1954 from the Silurian. Proposing that this extremely small sample is, however, representative for these taxa, we aim to describe in detail the growth of an element from each of these taxa in order to the test the following hypotheses: (1) Panderodus and Proconodontus processed hard food, which led to damage of their elements consistent with prey capture function; and (2) both genera shifted towards higher trophic levels during ontogeny. We employed backscatter electron (BSE) imaging, energy-dispersive X-Ray spectroscopy (EDX) and synchrotron radiation X-ray tomographic microscopy (SRXTM) to identify growth increments, wear and damage surfaces, and the Sr/Ca ratio in bioapatite as a proxy for the trophic position. Using these data, we can identify whether they exhibit determinate or indeterminate growth and whether both species followed linear or allometric growth dynamics. Growth increments (27 in Pa. equicostatus and 58 in Pr. muelleri) were formed in bundles of 4-7 increments in Pa. equicostatus and 7-9 in Pr. muelleri. We interpret the bundles as analogous to Retzius periodicity in vertebrate teeth. Based on applied optimal resource allocation models, internal periodicity might explain indeterminate growth in both species. 
They also allow us to interpret the almost linear growth of both individuals as an indicator that there was no size-dependent increase in mortality in the ecosystems where they lived e.g., as would be the case in the presence of larger predators . Our findings show that periodic growth was present in early conodonts and preceded tissue repair in response to wear and damage. We found no microwear and the Sr/Ca ratio, and therefore the trophic position, did not change substantially during the lifetimes of either individual. Trophic ecology of coniform conodonts differed from the predatory and/or scavenger lifestyle documented for "complex" conodonts. We propose that conodonts adapted their life histories to top-down controlled ecosystems during the Nekton Revolution. 
1 Growth and feeding ecology of coniform conodonts

2

3

4

5

6

7

\section{8}

Isabella Leonhard ${ }^{1}$, Bryan Shirley², Duncan Murdock ${ }^{3}$, John Repetski ${ }^{4}$, Emilia Jarochowska ${ }^{5}$

${ }^{1}$ Institute of Evolutionary Biology, University of Warsaw, ul. Żwirki i Wigury 101, 02-089 Warszawa, Poland

${ }^{2}$ Paläoumwelt, Friedrich-Alexander-Universität Erlangen-Nürnberg, Loewenichstr. 28, 91054 Erlangen, Germany

${ }^{3}$ Oxford University Museum of Natural History, Parks Road, Oxford OX1 3PW, UK

${ }^{4}$ US Geological Survey-Emeritus, MS 926A National Center, Reston, VA 20192, USA

${ }^{5}$ Department of Earth Sciences, Utrecht University, Princetonlaan 8a, 3584 CB Utrecht, The Netherlands

Corresponding Author: Isabella Leonhard Institute of Evolutionary Biology, University of Warsaw, ul. Żwirki i Wigury 101, 02-089 Warszawa, Poland Email address: i.leonhard@uw.edu.pl

\section{Abstract}

Conodonts were the first vertebrates to develop mineralized dental tools, known as elements.

Recent research suggests that conodonts were macrophagous predators and/or scavengers but we do not know how this feeding habit emerged in the earliest coniform conodonts, since most studies focus on the derived, 'complex' conodonts. Previous modelling of element position and mechanical properties indicate they were capable of food processing. A direct test would be provided through evidence of in vivo element crown tissue damage or through in vivo incorporated chemical proxies for a shift in their trophic position during ontogeny. Here we focus on coniform elements from two conodont taxa, the phylogenetically primitive Proconodontus muelleri Miller, 1969 from the late Cambrian and the more derived Panderodus equicostatus Rhodes, 1954 from the Silurian. Proposing that this extremely small sample is, however, representative for these taxa, we aim to describe in detail the growth of an element from each of these taxa in order to the test the following hypotheses: (1) Panderodus and Proconodontus processed hard food, which led to damage of their elements consistent with prey capture function; and (2) both genera shifted towards higher trophic levels during ontogeny. We employed backscatter electron (BSE) imaging, energy-dispersive X-Ray spectroscopy (EDX) and synchrotron radiation X-ray tomographic microscopy (SRXTM) to identify growth increments, wear and damage surfaces, and the $\mathrm{Sr} / \mathrm{Ca}$ ratio in bioapatite as a proxy for the trophic 
40 position. Using these data, we can identify whether they exhibit determinate or indeterminate

41 growth and whether both species followed linear or allometric growth dynamics.

42 Growth increments (27 in Pa. equicostatus and 58 in Pr. muelleri) were formed in bundles of 4-7

43 increments in Pa. equicostatus and 7-9 in Pr. muelleri. We interpret the bundles as analogous to

44 Retzius periodicity in vertebrate teeth. Based on applied optimal resource allocation models,

45 internal periodicity might explain indeterminate growth in both species. They also allow us to

46 interpret the almost linear growth of both individuals as an indicator that there was no size-

47 dependent increase in mortality in the ecosystems where they lived e.g., as would be the case in

48 the presence of larger predators. Our findings show that periodic growth was present in early

49 conodonts and preceded tissue repair in response to wear and damage. We found no microwear

50 and the $\mathrm{Sr} / \mathrm{Ca}$ ratio, and therefore the trophic position, did not change substantially during the

51 lifetimes of either individual. Trophic ecology of coniform conodonts differed from the

52 predatory and/or scavenger lifestyle documented for "complex" conodonts. We propose that

53 conodonts adapted their life histories to top-down controlled ecosystems during the Nekton

54 Revolution.

55

\section{Introduction}

57 Conodonts are marine, eel-like jawless vertebrates occurring in marine ecosystems from the

58 Cambrian to the Late Triassic. As the first marine vertebrates possessing a mineralized skeleton

59 (Sweet \& Donoghue, 2001), conodonts receive special attention from researchers for several

60 reasons. Their oropharyngeal cavity contained an array of phosphatic dental tools known as

61 elements. Biostratigraphic and geochemical studies are commonly conducted on these elements,

62 thanks in part to their abundance in marine carbonates, complex morphology, and geochemical

63 stability (Boaz et al., 1984; Trotter et al., 2007; Joachimski \& Buggisch, 2002; Joachimski et al.,

64 2009). In spite of their utility, the ecology and feeding strategies of conodonts remain enigmatic.

65 Elements range from simple cone-shaped, or 'coniform', morphologies in more primitive groups

66 _. . to comb-like and platform-bearing ('complex') forms, which are arranged in bilaterally

67 symmetrical multi element feeding apparatus (Aldridge et al., 1993). Their highly diverse

68 morphology strongly indicates an enormous range of feeding ecologies (Girard \& Renaud 2012;

69 Murdock, Rayfield \& Donoghue, 2014; Martínez-Pérez et al., 2016; Petryshen et al., 2020).

70 Furthermore, conodonts provide a great resource to identify general functional principles of the

71 evolution of dental tools at the biomechanical, morphological and histological level (Jones, 2009;

72 Jones et al., 2012; Dzik, 2015; Martínez-Pérez et al., 2016; Guenser et al., 2019; Petryshen et al.,

73 2020). Multiple modes of feeding have been proposed in the past, but only the macrophagous

74 predator or scavenger (Aldridge et al., 1986) and filtering as a microphagous active suspension

75 feeder (Nicoll \& Rexroad, 1987) are compatible with the conodont body plan (Purnell \&

76 Donoghue, 1997). These interpretations have been established in quantitative studies on growth

77 dynamics (Armstrong \& Smith, 2001; Zhang, Aldridge \& Donoghue, 1997), histology

78 (Donoghue, 1997) and chemical composition (Shirley et al., 2018; Balter et al., 2019) carried out

79 mostly on "complex" conodonts. However, there is little evidence how feeding strategies evolved 
80

81

82

83

84

85

86

87

88

89

90

91

92

93

94

95

96

97

98

99

100

101

102

103

104

105

106

107

108

109

110

111

112

113

114

115

116

117

118

119

within the very early coniform conodonts (Murdock, Sansom \& Donoghue, 2013; Murdock, Rayfield \& Donoghue, 2014). Here we attempt to pinpoint the assembly of morphogenetic and life history adaptations at the origin of predation within the earliest vertebrates.

\section{Apparatus reconstruction}

The coniform conodont genus Panderodus is regarded by most researchers to be the only known coniform taxon represented by almost complete fused clusters (An et al., 1983; Kozur, 1984; Dzik \& Drygant, 1986) and natural assemblages (Smith, Briggs \& Aldridge, 1987; Murdock \& Smith, 2021a). Multiple reconstructions of its apparatus have been proposed (e.g. Fåhræus \& Hunter, 1985; Dzik \& Drygant, 1986; Armstrong, 1990; Sansom, Armstrong \& Smith, 1994), with the most recent synthesis proposed by Murdock \& Smith (2021a). According to the reconstruction of Sansom, Armstrong \& Smith (1994) and Murdock \& Smith (2021a), the apparatus of Panderodus consists of 17 cone-shaped, laterally furrowed and non-geniculate elements assigned to six morphotypes arranged symmetrical across the midline. Sansom, Armstrong \& Smith (1994) subdivided the elements into three architectural units. The costate suite anterior of the apparatus comprises arcuatiform, graciliform and truncatiform elements. The compressed posterior suite consists of falciform and tortiform elements and the last unit is the unpaired symmetrical aequaliform element on the midline. The most recent reconstruction of Murdock \& Smith (2021a) allows to identify homologies with feeding apparatuses of more derived conodonts, with differentiation between grasping $\mathrm{M}$ and $\mathrm{S}$ elements (rostrally) and caudally located P elements for food processing (Aldridge et al., 1993). According to the newest data, the costate element suite consists of arcuatiform, as well as of four pairs of graciliform elements. The compressed, caudal suite comprises falciform, tortiform and truncatiform elements, while the unpaired aequaliform element exposes at the midline between costate and compressed suite and not at the very causal end of the apparatus as proposed earlier.

Apparatus reconstructions of the genus Proconodontus are more hypothetical as they are not based on natural assemblages and/or clusters. Proconodontus muelleri Miller, 1969 exhibits a trimembrate apparatus, comprising symmetrical (aequaliform), asymmetrical (graciliform) and compressed (arcuatiform) morphotypes (Szaniawski \& Bengtson, 1998).

\section{Function of coniform conodont elements}

Jeppsson (1979) discussed the use of "simple type conodonts" as teeth based on morphological similarities between actual teeth and conodont elements. Sansom, Armstrong \& Smith (1994) proposed functional differentiation within the apparatus of coniform conodonts because of morphological differences of single element morphotypes, and Szaniawski (2009) proposed that some coniform conodonts, including Panderodus, were venomous. This classification was corroborated by Murdock, Sansom \& Smith (2013) through the development of functional interpretations for each morphotype, using biomechanical proxies to infer their relative propensity for a cutting or grasping function. 
120

121

122

123

124

125

126

127

128

129

130

131

132

133

134

135

136

137

138

139

140

141

142

143

144

145

146

147

148

149

150

151

152

153

154

155

156

157

158

159

Internal structure

Euconodont (or "true conodonts") elements consist of hypermineralized crown tissue and the dentine-like basal body (Bengtson, 1976). The basal body is organic-rich, poorly mineralized and rarely preserved (Lindström, 1964; Souquet \& Goudemand, 2020). The crown tissue is composed of hyaline lamellar tissue and, in some conodont taxa, white matter, which is unique to conodonts (Pander, 1856; Hass, 1941; Müller \& Nogami, 1971). The lamellar tissue consists of individual growth layers that accrete appositionally throughout the life of the animal (Müller \& Nogami, 1971; Donoghue, 1998). The enamel-like structure of the lamellar tissue has been proposed to be an adaptation to dental function (Donoghue, 2001), a hypothesis supported by Finite Element Analyses of early coniform conodonts (Murdock, Rayfield \& Donoghue 2014). It has been suggested that white matter is a further adaptation to dental function by allowing the elements to withstand greater tensile stresses (Jones et al., 2012).

\section{Element growth}

Conodont elements grew by periodic, appositional accretion of new lamellar crown increments (Bengtson, 1976; Donoghue, 1997), speculated to reflect daily periods of growth (Zhang, Aldridge \& Donoghue 1997; Dzik, 2008; Świś, 2018). Deposition of lamellae in bundles, i.e. periodicity, within conodont crown tissue has been observed in "complex" conodonts (Zhang, Aldridge \& Donoghue 1997; Chen et al., 2016), as well as in coniforms (Armstrong \& Smith, 2001). Shirley et al. (2018) showed that these bundles correspond to periods of repair after surface damage resulting from food processing. The distribution of such abraded and truncated surfaces on elements corresponds to patterns of microwear distribution observed on their surfaces (Purnell, 1995; Jones et al., 2012). Alternatively, such internal discontinuities have been interpreted as structures resulting from accidental damage followed by repair (Hass, 1941) or abnormal deformation during growth (Rhodes, 1954). Purnell (1995) interpreted them as evidence for phases of growth and function based on consistent occurrence, which was corroborated by Donoghue (1998). Distinct growth dynamics and morphology between the early ontogenetic and adult phase have been observed in several conodont taxa (Armstrong \& Smith, 2001) and further supported by differences in chemical composition (Shirley et al., 2018).

\section{Chemical proxies for the trophic position}

Conodont chemical composition has been determined by Pietzner et al. (1968) as consistent with francolite and close to the non-stoichiometric formula $\mathrm{Ca}_{5} \mathrm{Na}_{0.14}\left(\mathrm{CO}_{3}\right)_{0.16}\left(\mathrm{PO}_{4}\right)_{3.01}\left(\mathrm{H}_{2} \mathrm{O}\right)_{0.85} \mathrm{~F}_{0.73}$ (Joachimski et al., 2009). In addition, alkali-earth elements ( $\mathrm{Sr}, \mathrm{Ba}$ and $\mathrm{Mg}$ ), as well as divalent metals, substitute $\mathrm{Ca}, \mathrm{Na}$ and $\mathrm{F}$ in vivo (Reynard \& Balter, 2014). Rare Earth elements (REE) and high-field strength elements are incorporated biostratinomically (Wright, Seymour \& Shaw 1984; Trotter \& Eggins, 2006; Reynard \& Balter, 2014; Žigaitè et al., 2019). As a nonessential element, strontium is increasingly depleted relative to the essential element $\mathrm{Ca}$ at each transition to a higher level in the trophic chain. This process is referred to as biopurification, resulting in lower Sr/Ca ratios with increasing trophic level (Comar, Russel \& Wasserman, 1957; Elias et al., 
160

161

162

163

164

165

166

167

168

169

170

171

172

173

174

175

176

177

178

179

180

181

182

183

184

185

186

187

188

189

190

191

192

193

194

195

196

197

198

199

1982). Strontium/calcium $(\mathrm{Sr} / \mathrm{Ca}$ ) ratio analysis of bone and teeth has been applied previously to investigate palaeodiets and relative positions of animals within the trophic network (Balter et al., 2002; Peek \& Clementz, 2012). This proxy has been mostly applied in terrestrial environments (e.g., Sillen, 1992; Sillen \& Lee-Thorp, 1994; Balter, 2004; Sponheimer et al., 2005), whereas similar investigations in marine food webs are lacking. It has been used successfully in modern environments and, even though the impact of bioapatite diagenesis (e.g. Ferretti et al., 2021) on the preservation of this proxy has not been investigated so far, it yields consistent results in fossil hypermineralized tissues (e.g. Balter et al., 2002; Sponheimer et al., 2005).

Wright (1989) demonstrated variations in Sr content within the lamellar tissue: light bands have higher $\mathrm{Sr}$ content than dark bands, which underpins visibility of the lamellae in BSE imaging. These observations were confirmed by several studies (e.g. Zhuravlev \& Shevchuk, 2017; Shirley et al., 2018). Additionally, individual growth stages of the "complex" conodont Ozarkodina confluens are distinguished by a decrease in crown tissue Sr content (Shirley et al., 2018), coincident with the appearance of histological record of dental wear in the adult animal.

Coniform conodonts

In this study, we focus on two coniform conodont species: the early Proconodontus muelleri Miller, 1969 (Proconodontidae: late Cambrian to Ordovician) and the more derived species Panderodus equicostatus Ethington, 1959 (Panderodontidae), which was widespread in Ordovician to Devonian oceans. Both species represent increased specialization of conodont apparatus during conodont evolution. Using backscatter electron (BSE) imaging and energydispersive X-ray spectroscopy (EDX), we test (1) if both conodont species processed hard food by analyzing whether their feeding behavior is manifest in damaged dental tissues; and (2) if both species shifted their trophic niche towards higher trophic levels during ontogeny, undergoing chemical and morphological changes in their crown tissues. Furthermore, we set out to identify whether these species show determinate or indeterminate growth and whether it follows linear or allometric dynamics, which might inform us on the evolution of life histories of these organisms. Growth periodicity has been previously observed in conodonts (Armstrong \& Smith, 2001) and attributed to episodes of repair following intensive feeding periods by Shirley et al. (2018). Here we aim to identify whether growth periodicity correlates with tissue damage and repair.

\section{Materials \& Methods}

We used two coniform conodont elements (Fig. 1); one truncatiform element (Fig. 1A-B) of Panderodus equicostatus Rhodes 1953 (for anatomical notation see Sansom, Armstrong \& Smith, 1994) from the Homerian (middle Silurian) shallow marine carbonates of the Ternava Formation at Vrublivtsy, Ukraine (sample V-19.25 in Jarochowska et al., 2016). It is stored in the collections of GeoZentrum Nordbayern (accession number EJ-12-V-19.25-001). The second specimen (Fig. 1C-F) is an aequaliform element (for anatomical notation see Müller, 1973) of Proconodontus muelleri Miller 1969 collected from Windfall Formation, Eureka County, 
200 Nevada, USA, dated at the Eoconodontus Zone, Furongian (Cambrian) (from sample 5-22-08D, 201 collected by J.D. Loch and J.F. Taylor; see Loch, Taylor \& Repetski (2019); will be stored at the 202 U.S. Geological Survey under the accession number DM_WI_Prc07).

203

204

205

206

207

208

209

210

211

212

213

214

215

216

217

218

219

220

221

222

223

224

225

226

227

228

229

230

231

232

233

234

235

236

237

238

239

\section{Synchrotron Radiation X-ray Tomographic Microscopy (SRXTM)}

Specimen [DM_WI_Prc07] (Pr. muelleri) was scanned at the TOMCAT X02DA beamline at the Swiss Light Source, Paul Scherrer Institute, Villigen, Switzerland. The sample was mounted on a $3 \mathrm{~mm}$ brass stub using an acetone soluble glue. A $20 \times$ objective, $17 \mathrm{keV}$ energy, and exposure time of $300 \mathrm{~ms}$ were used for the scan acquiring 1501 individual projections. These were then reconstructed using a 60-core Linux PC farm which applied a Fourier transform routine and a regridding procedure as outlined by Zhu et al., 2010. The subsequent model had voxel dimensions of $0.325 \mu \mathrm{m}$. Using Amira 2019, Slice data were segmented and cleaned to produce 3D models (Fig. 1E-F).

\section{Sample preparation}

Both samples were prepared following the method outlined by Shirley, et al., 2020. Conodonts were imbedded in epoxy resin (Epofix, 398, Struers) and the surfaces were ground and polished to create a flat and defect-free surface. This was followed by carbon coating up to $7 \mathrm{~nm}$ in thickness. Specimen photographs are stored on Morphobank (morphobank.org:

http://morphobank.org/permalink/?P35891ink; Specimen no. M681817 and M821733).

\section{Energy-dispersive X-ray spectroscopy}

Position of EDX transects with respect to conodont tissue was documented in BSE images obtained using a TESCAN Vegal $X X M U$ scanning electron microscope at GeoZentrum Nordbayern, Friedrich-Alexander-Universität Erlangen-Nürnberg. EDX analysis was performed using an Oxford Instruments X-MAX $50 \mathrm{~mm}$ silicon drift detector. The concentrations of major constituents ( $\mathrm{Sr}, \mathrm{F}, \mathrm{Mg}, \mathrm{P}, \mathrm{Na}, \mathrm{Ca}, \mathrm{O}$ ) of the conodont elements were measured along three line transects (Pr. muelleri; Fig. 2, Table S1) and six line transects (Pa. equicostatus; Fig. 3, Table S2) using a voltage of $15 \mathrm{KeV}$ with a spatial resolution of $\sim 3 \mu \mathrm{m}$ (Shirley, Bestmann \& Jarochowska, 2020). EDX was calibrated using a cobalt standard. All line transects were run for at least $45 \mathrm{~min}$, to quantify spatial trends of $\mathrm{Sr}$ and $\mathrm{Ca}$ concentration throughout basal body and crown tissue, as well as changes in the content of these elements in the crown lamellae. The elemental composition of single elements was measured as total number of counts (cts), with each point measured for the same time. This allows comparing relative $\mathrm{Sr}$ and $\mathrm{Ca}$ content between all spots in the line transect. We excluded measurements which fell into cracks within the element or into the resin. Since basal tissue with its high organic content does not preserve chemical concentration reliably, we focused on the $\mathrm{Sr}$ and $\mathrm{Ca}$ content within the crown tissue (Fig. 4).

All analyses were carried out using the R Software (R Core Team, 2020). A random slope and random intercept mixed-effects model was fitted in the lme4 package (Bates et al., 2015) to 
$240 \mathrm{Sr} / \mathrm{Ca}$ values in function of the distance from the inner side (occlusal side) of the element (fixed 241 effect) with transect and the side (inner, outer or tip) as random effects (Fig. 5 and Table S1; S2).

242 To account for different thicknesses of the crown tissue in different parts of the element, the

243 length of each transect was scaled to the $[0,1]$ interval (Leonhard et al., 2021).

244

245 Analysis of growth dynamics

246 High resolution BSE photographs were produced using Helios NanoLab 600i field emission FIB

247 SEM at the Department of Materials Science, Friedrich-Alexander-Universität Erlangen-

248 Nürnberg at $15 \mathrm{kV}$. One transect has been placed along one transect in each specimen (Figs. 2

249 and 3). Growth layers were counted and measured using the measurement tool in ImageJ (Fiji).

250 This was conducted on both elements on the convex side, which is assumed to be the non-

251 occlusal side of the element (Fig. 2 and Fig. 3). We attempted to fit von Bertalanffy and logistic

252 growth models using the package growthrates, but these models could not be fitted to the data

253 (see discussion). An OLS linear growth model was compared with an allometric model fitted

254 using the nls function with a self-starter from the aomisc package (Onofri, 2020) or using the drc 255 package (Ritz et al., 2015). Model selection was based on Akaike's Information Criterion (AIC).

256 The results are reported in Table 1 and in Figs 6B and 7B.

257

258

259 Growth dynamics

260 In both specimens, allometric growth models described the growth curves better than linear 261 models (Table 1; Figs 6B and 7B). Growth layers adjacent to the basal body in the $P a$.

262 equicostatus specimen were not clearly detectable (Fig. 7A). Further from the inner side of the 263 crown 27 (minimum estimate) growth layers with a mean width of $0.44 \mu \mathrm{m}$ were counted. We

264 measured an average of accretion of $13.10 \mu \mathrm{m}$ of the lamellar tissue on the non-occlusal side 265 (outer side) of the element. Growth dynamics followed an allometric model $y=0.6092 x^{0.8749}$ 266 (Table 1). The individual grew faster in the first third of its life until growth layer eight (mean 267 width $=0.472 \mu \mathrm{m}$ ), slowed down until growth layer 22 (mean width $=0.368 \mu \mathrm{m}$ ) and increased 268 the speed of growth towards the edge of the element (Fig. 7B; mean width $=0.423 \mu \mathrm{m}$ ). We 269 observed a periodicity (deposition of growth increments in bundles) with 4-7 growth increments 270 in six bundles (Fig. 7C).

271 Pr. muelleri had 58 growth layers (Fig. 6A) with a mean width of $0.543 \mu \mathrm{m}$ on the non-occlusal 272 side of the element (accretion of $29.579 \mu \mathrm{m}$ in total). The specimen followed allometric growth 273 described as $y=0.7891 \mathrm{x}^{0.9119}$ (Table 1). It grew faster within the first third of its life until growth 274 layer 18 (Fig. 6B; mean width $=0.62 \mu \mathrm{m}$ ), then it continued to grow at a constant rate before it 275 slowed down at growth layer 48 (mean width $=0.47 \mu \mathrm{m}$ ) towards the end of its construction. $\mathrm{Pr}$. 276 muelleri's growth showed periodicity with 7-9 growth increments per bundle (Fig. 6C). We 277 counted eight bundles of growth increments, which matched with the sequence of eight 278 truncated, irregular surfaces detected within the tip of the specimen (Fig. 8).

279 
280 Surface damage

281 No internal wear or damage surfaces could be detected in BSE sections through either of the 282 specimens. White matter, expected in the cusp of $P a$. equicostatus, was not detected under light 283 microscope (Fig. 1A) or BSE (Fig. 3). Pr. muelleri elements lack white matter. In the Pa.

284 equicostatus specimen, the lamellar tissue present in the tip area had porous interlamellar zones 285 such as those described by Müller \& Nogami (1971).

286

287

$\mathrm{Sr} / \mathrm{Ca}$ ratio

288 Mean \pm SD strontium content in Pa. equicostatus ranged from $206 \pm 23$ (transect 5) to $296 \pm 42$

289 (transect 1) cts and calcium content - from 3561 \pm 212 (transect 5) to $4593 \pm 166$ (transect 1) cts. In

290 Pr. muelleri, Sr content ranged from $321 \pm 22$ (transect 1) to $540 \pm 30$ (transect 3) cts and Ca

291 content - from $6346 \pm 284$ (transect 2) to $10323 \pm 140$ (transect 3) cts. The relative concentrations

292 per transect are summarized in Fig. 4. Systematic differences between transects have been

293 accounted for in the design of the random intercept mixed-effects model, allowing to compare

294 the results across the entire element.

295 The mixed effect model fitted to $\mathrm{Sr} / \mathrm{Ca}$ ratios across five transects placed through crown tissue of 296 Pa. equicostatus indicated an increase of $\mathrm{Sr} / \mathrm{Ca}$ during ontogeny and high variance between 297 individual transects. On the inner side of the element, all transects showed an increase, whereas 298 on the outer side, two out of the five examined transects recorded a decrease, reflecting the high 299 variability of the slopes (Fig. S1). We excluded transect six from the model since most of the 300 measured counts of $\mathrm{Sr}$ and $\mathrm{Ca}$ are lying within the basal body (Fig. 3). The fixed effect of the 301 distance from the inner edge of the lamellar crown tissue was estimated as $\mathrm{y}=0.011792 \mathrm{x}+$ $3020.056889(\mathrm{n}=647$, standard error for the intercept estimate 0.002815 and standard error for the 303 slope estimate 0.007881). The rate of increase was different on either side of the element, with 304 higher values on the inner side (slope coefficient 0.019 ) than on the outer side (0.004). The 305 strongest increase in $\mathrm{Sr} / \mathrm{Ca}$ was found along transect 4 (Tab. S3).

306 In Pr. muelleri, the mixed effects model fitted to $\mathrm{Sr} / \mathrm{Ca}$ ratios across three transects running 307 through the lamellar tissue (Figs 2, 5) indicated a decrease during ontogeny (Fig. S2), with the 308 fixed effect of the distance from the inner edge of the crown estimated as $y=-0.003149 \mathrm{x}+$ $3090.052491(\mathrm{n}=572$, standard error for the intercept estimate 0.001396 , standard error for the 310 slope estimate 0.002627). The side of the element had a greater effect on the intercept estimate, 311 with the highest values on the inner side (Tab. S3), whereas the slope was more affected by the 312 position of the transect, with an opposite sign (increasing $\mathrm{Sr} / \mathrm{Ca}$ ) along transect 3 running 313 through the tip of the element and with the strongest decrease along transect 2 (Tab. S3, Fig. S2). 314 Apart from the weak increase of $\mathrm{Sr} / \mathrm{Ca}$ values through the tip of the element, individual estimates 315 calculated for each level of the random effects did not differ substantially from that of the fixed 316 effect.

317

318 Discussion

319 Element growth in Proconodontus muelleri and Panderodus equicostatus 
320 Neontological theories of growth dynamics rely on information on resource availability and the

321

322

323

324

325

326

327

328

329

330

331

332

333

334

335

336

337

338

339

340

341

342

343

344

345

346

347

348

349

350

351

352

353

354

355

356

357

358

359

network of interactions in which the organism engages; this information is not available for most fossils. Thus, interpretations of growth dynamics must rely on theoretical models. Here we attempt to apply simple predictions of optimal resource allocation models to interpret growth curves of Pa. equicostatus and Pr. muelleri. These models aim to predict the distribution of energy into somatic growth and reproduction, taking into account what size of the adult animal and of its offspring allows for the best resource acquisition and the lowest mortality. Here we observed indeterminate growth, i.e. growth throughout the life of the individual (Lincoln, Boxshall \& Clark, 1982). We can exclude that the specimens were immature because their measured element length (Pa. equicostatus: $725 \mu \mathrm{m}$; Pr. muelleri: $782 \mu \mathrm{m}$ ) is in the upper third of average element length of most illustrated specimens of the same species in recent literature (supplementary Material: Fig. 1). Thus, we can be certain that their growth, which was best described by a power equation, but close to linear, was representative of their life history and not limited to the linear growth phase, which is characteristic e.g. for fish before they reach sexual maturity (Sebens, 1987). The strongest theoretical predictor of indeterminate growth is seasonality (Kozlowski, 2006), because seasonality leads to a periodic shift in the benefits of growth and reproduction and incentivises repeated episodes of resource accumulation to reproduce in successive seasons. Growth dynamics similar to that induced by seasonality can be caused by design constraints, e.g. limits on the space for egg development in the body cavity or time needed for tissue maturation (Stamps, Mangel \& Phillips, 1998; Ricklefs, 2003). We suggest that conodonts were likely annual, multivoltine organisms, i.e. reproducing multiple times during the season. Periods of feeding and somatic growth alternating with periods where energy is allocated to reproduction are expected to lead to growth described by the logistic or von Bertalanffy's curves (Kozłowski, 2006). Distinguishing between these models was not possible with the proposed short conodont life spans examined here, but asymptotic indeterminate growth is seen in "complex" conodonts (Dzik, 2008; Shirley et al., 2018). The difference between the nearly-linear growth found in coniform conodonts described here and that characterized by a strong decrease in the growth rate e.g. in Oz. confluens (Shirley et al., 2018) or in the Tripodellus lineage (Dzik, 2008) is consistent with a stronger top-down control: slowing growth with age indicates allocating bigger fraction of energy into reproduction, which is an optimal strategy if mortality increases with size (e.g. when large predators are present in the ecosystem). Nearly linear growth as observed in Pr. muelleri and Pa. equicostatus is predicted to be optimal if size allows for more offspring without the risk of increased mortality, i.e. when growing bigger does not mean becoming an easier prey. Based on these simple predictions of optimal resource allocation models, it may be possible to exploit conodont sclerochronology to identify the evolution of life histories as early Palaeozoic trophic networks became more complex.

We recognize the limitations of a sample size of two elements from two taxa, and the discussion below is in the context of the degree to which these data can be extrapolated to other elements and taxa and the confidence we can place in the resulting conclusions.

Peer) reviewing PDF | (2021:07:63847:2:0:NEW 20 Oct 2021) 
360

361

362

363

364

365

366

367

368

369

370

371

372

373

374

375

376

377

378

379

380

381

382

383

384

385

386

387

388

389

390

391

392

393

394

395

396

397

398

399

\section{Damage and wear}

Complex conodont elements exhibit repeated episodes of wear and damage within their crown tissues, indicating dental function (Purnell, 1995; Donoghue \& Purnell, 1999; Purnell \& Jones, 2012; Shirley et al., 2018). In the few taxa known from clusters, the distribution of wear and damage appears to match the occlusal contact between pairs of elements within the apparatus (Donoghue \& Purnell, 1999). A limitation of studies available so far is that patterns of damage are either described on element surfaces or in histological sections, but these two aspects surface and internal structure - have not been compared in the same element. Consequently, of the various types of wear and damage identified by Purnell \& Jones (2012), it is mostly breakage that has also been identified in histological sections, including in coniform conodonts (Hass, 1941; Barnes, Sass \& Monroe, 1970; Müller \& Nogami, 1971; Barnes, Sass \& Poplawski, 1973; Nazarova \& Kononova, 2020). On the element surface, breakage can only be detected when it has been so extensive that the original shape of the element could not be fully restored. In such cases the tips of cusps appear smaller in diameter where regeneration has taken place. Smallerscale wear and damage, such as polishing and rounding described from surfaces of "complex" conodonts by Purnell \& Jones (2012), are not likely to leave any trace if they had already been covered by the next episode of tissue deposition. We are not aware of any reports of such damage in coniform conodonts.

Implications for other types of elements in the apparatus

Murdock, Sansom \& Donoghue (2013) documented morphological and functional specialization of elements in the Panderodus apparatus and characterized the anterior (costate) element suite as represented by larger elements that are most resistant to bending and torsion. However, the reexamination of the feeding apparatus of Panderodus by Murdock \& Smith (2021a) positioned the truncatiform element not within the costate suite, but in the compressed, posterior suite. Its new position does not alter the examined resistance to bending and torsion and has no effect on its functional specialization.

Truncatiform elements examined here are more resistant to bending in one direction, which is interpreted to be characteristic of element types which functioned as blades and were used for cutting prey items. Truncatiform elements of Panderodus have been also placed by Murdock, Sansom \& Donoghue, (2013) in the functional unit of the apparatus characterised by the lowest resistance to torsion, which would correspond to elements not involved in prey restraint (Murdock \& Smith, 2021b: https://datadryad.org/stash/dataset/doi:10.5061/dryad.0p2ngf20z). Elements with a cutting function, i.e. arcuatiform, truncatiform and falciform, would be the most likely candidates to show surface wear and damage; the fact that we could not identify it in a truncatiform element suggests that this lack is representative for the entire apparatus of $P a$. equicostatus.

The apparatus of Proconodontus has lower morphological and, most likely, lower functional differentiation than Panderodus (Sansom, Armstrong \& Smith1994). The apparatus of Pr. muelleri has been reconstructed as a multielement apparatus (Szaniawski \& Bengston, 1998)

Peer) reviewing PDF | (2021:07:63847:2:0:NEW 20 Oct 2021) 
400 based on discrete elements only. We could not identify undebatable wear or damage surfaces in 401 the aequaliform element of this species. If the functional interpretation developed for 402 Panderodus by Murdock, Sansom \& Donoghue (2013) is applied to Pr. muelleri, the symmetry 403 of aequaliform elements likely results in an equally distributed resistance to bending in all 404 directions. This property was interpreted in Panderodus as an adaptation for prey capture and 405 restraint (Murdock, Sansom \& Donoghue 2013). It is possible, therefore, that wear and damage 406 could be present only in elements interpreted to perform cutting function, i.e. arcuatiform, 407 truncatiform and falciform. In Panderodus, the aequaliform element was placed by Sansom, 408 Armstrong \& Smith (1994) in the posterior-most functional unit with the lowest average 409 resistance to torsion, which was therefore interpreted as not involved in restraining the prey item 410 (Murdock, Sansom \& Donoghue,2013). However, regarding the most recent reconstruction by 411 Murdock \& Smith (2021a) for the Panderodus apparatus, the aequaliform element was exposed 412 on the midline between the anterior and posterior suite.

413 But symmetrical elements, i.e. truncatiform and aequaliform, have relatively high resistance to 414 torsion. Furthermore, morphological specialization of element types in Proconodontus 415 apparatuses appears to be less pronounced, with many transitional forms reported within single 416 populations (Szaniawski \& Bengtson, 1998). Consequently, in a less specialized apparatus likely 417 all elements engaged with the prey items and their functions overlapped to a larger extent than 418 they did in Panderodus.

419

420

Implications for other conodont taxa

422

423

424

425 Sansom, Armstrong \& Smith (1994) proposed a division of the Panderodus apparatus into three functional units, applicable to all species. Subsequent analysis of individual morphologies proposed that this division did not capture the degree of specialization of individual elements (Murdock et al, 2013). Shape features which formed the basis of this functional analysis are largely preserved and recognizable across the genus and are, in fact, used to identify element types (e.g. Sansom, Armstrong \& Smith, 1994; Jeppsson, 1997). Finite Element Analysis comparing Proconodontus, i.e. conodonts with crown tissues, and the paraconodont Furnishina, devoid of crown tissues, indicate that histological differentiation has an even larger impact on mechanical properties than the shape alone (Murdock, Rayfield \& Donoghue 2014). Panderodus species differ systematically in the proportion of crown tissues and the depth of their basal cavity (which is in vivo filled with dentine-like basal tissue) and these systematic differences are the basis for species diagnoses. In particular, some species such as Panderodus panderi, have a much higher proportion of white matter than $P a$. equicostatus examined here. As the mechanical analysis by Murdock, Sansom \& Donoghue (2013) relied exclusively on element outlines and not on the histological composition, it is likely that the functional differentiation within the apparatus of any given Panderodus species would remain the same, regardless of speciesspecific histological differences.

439 Elements of Proconodontus differ in the inner structure (basal cavity to crown ratio) and their morphology between species. The genus is one of the very early and primitive euconodonts with 
440 striking morphological similarities to their ancestors (paraconodonts) but with a crucial 441 apomorphy, the crown tissue (Miller \& Hinz-Schallreuter, 1998; Murdock, Rayfield \&

442 Donoghue, 2014). The expansion of the crown and the simultaneous reduction of the basal body

443 may be one of the leading factors towards high morphological and functional diversity in

444 euconodonts, leading to their great diversity in feeding ecology (Murdock, Rayfield \& Donoghue

445 2014). Elements of Pr. muelleri exhibit relatively deep basal cavities (Fig. 1), whereas other

446 species feature proportionally thicker crowns, presumably to distribute stress more evenly while

447 functioning (Jones et al., 2012).

448

449 Growth periodicity

450 Growth layers were grouped into bundles of 4-7 and 7-9 in, respectively, Pa. equicostatus and

451 Pr. muelleri. These bundles are shorter than the "major increments" with averages of 16-17

452 increments, observed in coniform conodonts Protopanderodus varicostatus and in Drepanodus

453 robustus by Armstrong \& Smith(2001).

454 Correlation between bundles of growth increments and periods of dental function visible as

455 damage on the occlusal surface observed in $\mathrm{Oz}$. confluens were interpreted by Shirley et al.

456 (2018) as support for the model of conodont growth in which periods of element use

457 corresponded to growth arrest and alternated with element repair (Bengtson, 1976; Zhang,

458 Aldridge \& Donoghue, 1997). On the other hand, the lack of damage and repair found in this

459 study suggests that, at least in these elements, periodicity was present even in the lack of repair

460 periods. These bear a resemblance to Retzius Periodicity, which is driven by an unknown

461 internal biorhythm and is not associated with any functional periodicity, marking bundles of

462 daily cross-striations in mammals (Boyde, 1989; Antoine, Hillson \& Dean, 2009). In such case,

463 the repair cycle following the circaseptan growth periodicity might have been an exaptation.

464 Assuming no periods of growth arrest during each cycle, i.e. if the number of growth layers is

465 taken at face value, the life span of early coniforms, Pr. muelleri, Protopanderodus varicostatus

466 and Drepanodus robustus, appears to be longer than that of the derived genus Panderodus

467 examined here, as well as that of "complex" conodonts. Those studies which examined multiple

468 specimens per sample reported small intraspecific variation, suggesting that values obtained here 469 are representative for the respective species.

470

471 Trophic shifts during ontogeny

$472 \mathrm{Sr} / \mathrm{Ca}$ ratio analysis of skeletal tissues has been applied previously to investigate palaeodiets and

473 relative positions of animals within the trophic network (Balter et al., 2002; Peek \& Clementz,

474 2012). However, environmental conditions (e.g. water chemistry, temperature or salinity) can

475 affect these ratios (e.g. de Villiers, 1999; Zimmerman, 2005; Martin \& Thorrold, 2005): changes

476 in the $\mathrm{Sr}$ content and/or $\mathrm{Sr} / \mathrm{Ca}$ ratio in skeletal tissues can potentially reflect migration of the

477 organism over distances or across the temperature gradient within the water column (de Villiers,

478 1999; Shirley et al., 2018). 
479 Based on the sedimentological record (see geological setting in Jarochowska et al., 2016), Pa.

480 equicostatus lived on a shallow carbonate platform without a substantial temperature gradient.

481 Pr. muelleri has been interpreted as having had a pelagic mode of life (Miller, 1984), therefore it

482 probably stayed within the surface waters above the thermocline. We are, therefore, confident

483 that the $\mathrm{Sr} / \mathrm{Ca}$ ratios observed here can be attributed to trophic level rather than fluctuating

484 environmental conditions.

485 Contrary to expectations based on "complex" conodonts, chemical proxies for the trophic

486 position did not indicate changes in this position during the ontogeny of Pr. muelleri and Pa.

487 equicostatus. The $\mathrm{Sr} / \mathrm{Ca}$ ratio, proposed as a proxy for the trophic position, changed only

488 minimally throughout the ontogeny in both species and in opposite directions: it decreased, as

489 predicted based on comparisons with Ozarkodina confluens (Shirley et al., 2018), in Pr. muelleri,

490 but increased by ca $1 \%$ per $1 \mu \mathrm{m}$ in Pa. equicostatus. These results indicate that neither species

491 changed their trophic niche substantially during their life. The study by Shirley et al., 2018 was

492 the first one investigating Sr content during ontogeny of the "complex" conodont Ozarkodina

493 confluens. The decrease in Sr contents in crown tissue (Shirley et al., 2018) was attributed to

494 "biopurification" in the trophic network and was in this species coincident with the appearance of

495 histological record of damage along occlusal surfaces in the adult animal. During its early life,

496 the animal fed at a lower trophic level than the adult, which was interpreted to have adopted a

497 predatory or scavenger lifestyle. Here we refined this proxy by measuring the $\mathrm{Sr} / \mathrm{Ca}$ ratio and not

498 the Sr contents. This should not render comparison impossible, because $\mathrm{Sr}$ is the most common

499 ion to replace $\mathrm{Ca}$ in the francolite lattice.

500 Our results indicate that either species did not change their trophic niche substantially during

501 their life, coinciding with almost linear growth. Lack of trophic differentiation in these species is

502 consistent with lack of tissue damage which could record dental function. Concurrent chemical

503 and histological observations do not yield any evidence for direct occlusal and predatory habit of

504 Pr. muelleri and Pa. equicostatus which has been demonstrated for "complex" conodonts

505 (Purnell, 1995; Jones, 2009; Jones et al., 2012; Martínez-Pérez et al., 2016; Shirley et al., 2018).

506

\section{Conclusions}

508 We used two coniform conodont elements, the phylogenetically primitive late Cambrian

509 Proconodontus muelleri and the more derived Silurian Panderodus equicostatus, to test the

510 hypothesis whether their adult forms fed as predators or scavengers. Unlike in "complex"

511 conodonts, no damage of the crown tissue, which is indicative of dental function, could be

512 detected in histological sections. An independent chemical proxy, the $\mathrm{Sr} / \mathrm{Ca}$ ratio, which was

513 expected to decrease with the trophic level, did not indicate shifts in the trophic position in the

514 two examined specimens Growth increments formed bundles of 4-7 in the crown tissue of Pr.

515 muelleri and 7-9 in Pa. equicostatus, respectively, which we interpret as driven by an internal

516 clock and analogous to Retzius Periodicity in vertebrate teeth. This finding contradicts our

517 previous interpretation that periodicity was an adaptation to tissue repair following damage

518 (Shirley et al., 2018) and indicates that the circaseptan rhythm was present in conodonts even in 
519 the absence of tissue damage during feeding periods. Internal periodicity is consistent with 520 indeterminate growth in conodonts when interpreted in the context of optimal resource allocation

521 models (Kozlowski, 2006). Repeated periods of growth would shift resource allocation away

522 from reproduction. Although conodont growth dynamics have not been investigated

523 systematically, growth curves in Pa. equicostatus and Pr. muelleri do not have strong asymptotes 524 as observed in "complex" conodonts (Dzik, 2008; Shirley et al., 2018). Such growth dynamics is 525 predicted to be optimal where there is no size-dependent increase in mortality, such as in the 526 absence of larger predators which would preferentially target large individuals. The limitations 527 of our study are that we examined only a single element and only one type of element in each 528 apparatus: truncatiform in Panderodus equicostatus and aequaliform in Proconodontus muelleri. 529 Given functional differentiation of these apparatuses (Sansom, Armstrong \& Smith, 1994; 530 Murdock, Sansom \& Donoghue, 2013; Murdock \& Smith, 2021), it is not certain whether the

531

532

533

534

535

536

537

538

539

540

541

542

543

544

545

546

547

548

549

550

551

552

553

554

555

556

557 lack of tissue damage is representative of the entire apparatus. Chemical and sclerochronological records, however, are expected to be consistent for the entire individual. Our study suggests that trophic ecology of coniform conodonts in early Palaeozoic ecosystems differed from that of predators or scavengers documented for "complex" conodonts. Our results suggest also that conodonts underwent an evolution of their life histories towards a top-down control consistent with the appearance of large predators by the Silurian Period (Klug et al., 2017).

\section{Acknowledgements}

We thank Birgit Leipner-Mata for help in preparation of sections and Christian Schulbert for help with SEM. We thank J.D. Loch and J.F. Taylor for obtaining the Windfall samples. We thank the Federica Marone (Swiss Light Source, Paul Scherrer Institut, Villigen, Switzerland) for access to the beamline and for invaluable assistance in collecting SRXTM data. Any use of trade, firm, or product names is for descriptive purposes only and does not imply endorsement by the U.S. Government. The manuscript benefited from constructive reviews by Marc Leu, Annalisa Ferretti and Yanlong Chen.

\section{References}

Aldridge, R. J., Briggs, D., Clarkson, E. N. and Smith, M. P. (1986) 'The affinities of conodontsnew evidence from the Carboniferous of Edinburgh, Scotland', Lethaia, vol. 19, no. 4, pp. 280291.

Aldridge, R. J., Briggs, D., Smith, M. P., Clarkson, E. and Clark, N. (1993) 'The anatomy of conodonts', The Royal Society, vol. 340, pp. 405-421.

An, T., Zhang, F., Xiang, W., Zhan, Y., Xu, W., Zhang, H., Jiang, D., Yang, C., Lin, L., Cui Z., Yang, X. (1983) 'The conodonts of north China and the adjacent regions', Science Press of China, pp. 223 
558

559

560

561

562

563

564

565

566

567

568

569

570

571

572

573

574

575

576

577

578

579

580

581

582

583

584

585

586

587

588

589

590

591

592

593

594

595

596

597

598

599

600

601

Antoine, D., Hillson, S. and Dean, M. C. (2009) 'The developmental clock of dental enamel: a test for the periodicity of prism cross-striations in modern humans and an evaluation of the most likely sources of error in histological studies of this kind', Journal of Anatomy, vol. 214, no. 1, pp. 45-55.

Armstrong, H. A., Clarkson, E. N. K. and Owen, A. W. (1990) 'A new Lower Ordovician conodont faunule from the Northern Belt of the Southern Uplands', Scottish Journal of Geology, vol. 26, no. 1, pp. 47-52.

Armstrong, H. A. and Smith, C. J. (2001) 'Growth patterns in euconodont crown enamel: implications for life history and mode-of-life reconstruction in the earliest vertebrates', Proceedings of the Royal Society: Biological Sciences, vol. 268, no. 1469, pp. 815-820. Balter, V. (2004) 'Allometric constraints on $\mathrm{Sr} / \mathrm{Ca}$ and $\mathrm{Ba} / \mathrm{Ca}$ partitioning in terrestrial mammalian trophic chains', Oecologia, vol. 139, no. 1, pp. 83-88.

Balter, V., Bocherens, H., Person, A., Labourdette, N., Renard, M. and Vandermeersch, B. (2002) 'Ecological and physiological variability of $\mathrm{Sr} / \mathrm{Ca}$ and $\mathrm{Ba} / \mathrm{Ca}$ in mammals of Western European mid-Würmian food webs', Palaeogeography, Palaeoclimatology, Palaeoecology, vol. 186, pp. 127-143.

Balter, V., Braga, J., Télouk, P. and Thackeray, J. F. (2012) 'Evidence for dietary change but not landscape use in South African early hominins', Nature, vol. 7417, pp. 558-560.

Balter, V., Martin, J. E., Tacail, T., Suan, G., Renaud, S. and Girard, C. (2019) 'Calcium stable isotopes place Devonian conodonts as first level consumers', Geochemical Perspectives Letters, vol. 10, pp. 36-39.

Barnes, C., Sass, D. B. and Monroe, E. A. (1970) 'Preliminary studies of the ultrastructure of selected Ordovician conodonts', Life Sciences Contribution Royal Ontario Museum, vol. 76. Barnes, C. R., Sass, D. B. and Poplawski, M. (1973) 'Conodont ultrastructure: the family Panderodontidae', Life Sciences Contribution Royal Ontario Museum, vol. 90.

Bates, D., Mächler, M., Bolker, B. and Walker, S. (2015) 'Fitting Linear Mixed-Effects Models using Ime4', Journal of Statistical Software, vol. 67, no. 1.

Bengston, S. (1983) 'The early history of the conodonta', Fossils and Strata, vol. 15, pp. 5-19.

Boaz, L., Kolodny, Y. and Kovach, J. (1984) 'Oxygen isotope variations in phosphate of biogenic apatites, III. Conodonts', Earth and Planetary Science Letters, vol. 69, pp. 255-262.

Boyde, A., Fortelius, M., Lester, K. S. and Martin, L. B. (1989) 'Basis of the structure and development of mammalian enamel as seen by scanning electron microscopy', Scanning Microscopy, vol. 2, no. 3, 1579-1490.

Bromage, T. G. and Dean, M. C. (1985) 'Re-evaluation of the age at death of immature fossil hominids', Nature, vol. 317, pp. 525-527.

Chen, Y., Neubauer, T. A., Krystyn, L. and Richoz, S. (2016) 'Allometry in Anisian (Middle Triassic) segminiplanate conodonts and its implications for conodont taxonomy', Palaeontology, vol. 59, no. 5, pp. 725-741.

Comar, C. L., Russell, R. and Wasserman, R. H. (1957) 'Strontium-Calcium Movement from Soil to Man', Science, vol. 126, no. 3272, pp. 485-492. de Villiers, S. (1999) 'Seawater strontium and Sr/Ca variability in the Atlantic and Pacific oceans', Earth and Planetary Science Letters, vol. 171, no. 4, pp. 623-634.

Donoghue, P. C. (2001) 'Microstructural variation in conodont enamel is a functional adaptation', Proceedings of the Royal Society: Biological Sciences, vol. 268, no. 1477, pp. 1691-1698. 
602 Donoghue, P. C. J. and Purnell, M. A. (1999) 'Mammal-like occlusions in conodonts',

603 Paleobiology, vol. 25, no. 1, pp. 58-74.

604 Donoghue, P. C. J. (1998) 'Growth and patterning in conodont skeleton', Philosophical

605 Transactions of the Royal Society B, vol. 353, pp. 633-666.

606 Donoghue, P. C. J. and Purnell, M. A. (1999) 'Growth, function, and the conodont fossil record',

607 Geology, vol. 27, no. 3, pp. 251-254.

608 Donoghue, P. C. J., Purnell, M. A., Aldridge, R. J. and Zhang, S. (2008) 'The interrelationships

609 of 'complex' conodonts (Vertebrata)', Journal of Systematic Palaeontology, vol. 6, no. 2,

610 pp. 119-153.

611 Donoghue, P. C. J. and Sansom, I. J. (2002) 'Origin and early evolution of vertebrate

612 skeletonization', Microscopy Research and Technique, vol. 59, no. 5, pp. 352-372.

613 Donoghue, P. C. J., Forey, P. L. and Aldridge, R. J. (2000) 'Conodont affinity and chordate

614 phylogeny', Biological Reviews, vol. 75, pp. 191-251.

615 Donoghue, P. J., Purnell, M. A. and Aldridge, R. J. (1998) 'Conodont anatomy, chordate

616 phylogeny and vertebrate classification', Lethaia, vol. 31, pp. 211-219.

617 Dzik, J. (1976) 'Remarks on the evolution of Ordovician conodonts', Acta Palaentologica

618 Polonica, vol. 21, no. 4.

619 Dzik, J. (1991) 'Evolution of oral apparatuses in the conodont chordates', Acta Palaentologica

620 Polonica, vol. 36, pp. 265-323.

621 Dzik, J. (2008) 'Evolution of morphogenesis in 360-million-year-old conodont chordates

622 calibrated in days', Evolution \& Development, vol. 10, pp. 769-777.

623 Dzik, J. and Drygant, D. (1986) 'The apparatus of panderodontid conodonts', Lethaia, vol. 19,

624 pp. 133-141.

625 Elias, R. W., Hirao, Y. and Patterson, C. C. (1982) 'The circumvention of the natural

626 biopurification of calcium along nutrient pathways by atmospheric inputs of industrial lead',

627 Geochimica et Cosmochimica Acta, vol. 46, pp. 2561-2580.

628 Erickson, G. M. (1996) 'Incremental lines of von Ebner in dinosaurs and the assessment of tooth

629 replacement rates using growth line counts', Proceedings of the National Academy of Sciences

630 of the United States of America, vol. 93, no. 25, pp. 14623-14627.

631 Fåhræus, L. and Hunter, D. R. (1985) 'The curvature-transition series: integral part of some

632 simple-cone conodont apparratuses (Panderodontacea, Distacodontacea, Conodontata)', Acta

633 Palaentologica Polonica, vol. 30, 3-4, pp. 177-189.

634 Ferretti, A., Medici, L., Savioli, M., Mascia, M. T., \& Malferrari, D. (2021) 'Dead, fossil or alive:

635 Bioapatite diagenesis and fossilization', Palaeogeography, Palaeoclimatology, Palaeoecology,

636 no. 579, 110608.

637 Girard, C. and Renard, S. (2012) 'Disparity changes in 370 Ma Devonian fossils: The signature

638 of ecological dynamics?', PLoS one, vol. 7, no. 4.

639 Guenser, P., Souquet, L., Dolédec, S., Mazza, M., Rigo, M. and Goudemand, N. (2019)

640 'Deciphering the roles of environment and development in the evolution of a Late Triassic

641 assemblage of conodont elements', Paleobiology, vol. 45, no. 3, pp. 440-457.

642 Hass, W. (1941) 'Morphology of conodonts', Journal of Paleontology, vol. 15, no. 1, pp. 71-81.

643 Jarochowska, E., Munnecke, A., Frisch, K., Ray, D. C. and Castagner, A. (2016) 'Faunal and

644 facies changes through the mid Homerian (late Wenlock, Silurian) positive carbon isotope

645 excursion in Podolia, western Ukraine', Lethaia, vol. 49, no. 2, pp. 170-198. 
646

647

648

649

650

651

652

653

654

655

656

657

658

659

660

661

662

663

664

665

666

667

668

669

670

671

672

673

674

675

676

677

678

679

680

681

682

683

684

685

686

687

688

689

Joachimski, M. M., Buggisch, W. (2002) 'Conodont apatite $\delta 180$ signatures indicate climate cooling as a trigger of the Late Devonian', Geology, vol. 30, n. 8, p. 711.

Joachimski, M. M., Breisig, S., Buggisch, W., Talent, J. A., Mawson, R., Gereke, M., Morrow, J. R., Day, J. and Weddige, K. (2009) 'Devonian climate and reef evolution: Insights from oxygen isotopes in apatite', Earth and Planetary Science Letters, vol. 284, 3-4, pp. 599-609.

Jones, D. (2009) 'Directional evolution in the conodont Pterospathodus', Paleobiology, vol. 35, no. 3, pp. 413-431.

Jones, D., Evans, A. R., Rayfield, E. J., Siu, K. K. W. and Donoghue, P. C. J. (2012) 'Testing microstructural adaptation in the earliest dental tools', Biology letters, vol. 8, no. 6, pp. 952-955. Jones, D., Evans, A. R., Siu, K. K. W., Rayfield, E. J. and Donoghue, P. C. J. (2012) 'The sharpest tools in the box? Quantitative analysis of conodont element functional morphology', Proceedings of the Royal Society: Biological Sciences, vol. 279, no. 1739, pp. 2849-2854. Jones, D., Purnell, M. A. and Bitter, P. H. von (2009) 'Morphological criteria for recognising homology in isolated skeletal elements: comparison of traditional and morphometric approaches in conodonts', Palaeontology, vol. 52, no. 6, pp. 1243-1256.

Katsanevakis, S., Thessalou-Legaki, M., Karlou-Riga, C., Lefkaditou, E., Dimitriou, E. and Verriopoulos, G. (2007) 'Information-theory approach to allometric growth of marine organisms', Marine Biology, vol. 151, no. 3, pp. 949-959.

Katvala, E. C. and Henderson, C. M. (2012) 'Chemical element distributions within conodont elements and their functional implications', Palaeobiology, vol. 38, no. 3, pp. 447-458.

Klug, C., Frey, L., Pohle, A., Baets, K. de and Korn, D. (2017) 'Palaeozoic evolution of animal mouthparts', Bulletin of Geosciences, pp. 511-524.

Kozlowski, J. (2006) 'Why life histories are diverse', Polish Journal of Ecology, vol. 54, no. 4, pp. 585-605.

Kozur, H. (1984) 'Preliminary report about the silurian to middle Devonian sequences', Geologisch-Paläontologische Mitteilungen Inssbruck, vol. 13, no. 7, pp. 149-176.

Lennart Jeppsson (1979) 'Conodont element function', Lethaia, vol. 12, pp. 153-171.

Leonhard, I.; Shirley, O. S.; Murdock D. J. E.; Repetski, J.; Jarochowska, E. (2021) Data from:

'Growth and feeding ecology of coniform conodonts', available at

https://osf.io/9npz2/?view_only=063b79d2a2b94b779278e3414c444021

Lincoln, R. J., Boxshall, G. A. and Clark, P. F. (1982) 'A dictionary of ecology, evolution, and systematics', Cambridge University Press, Cambridge, Great Britain

Lindström, M. (1965) 'Conodonts', Nature, vol. 206, p. 646.

Loch, J. D., Taylor J.F. and Repetski, J. E. (2019) 'Lotagnostus-dominated faunas from the Cambrian Windfall Formation, Nevada, USA: Implications for deliberations over the base of Cambrian Stage 10', North American Paleontology Congress, Riverside, CA.

Martínez-Pérez, C., Plasencia, P., Jones, D., Kolar-Jurkovšek, T., Sha, J., Botella, H. and Donoghue, P. C. (2014) 'There is no general model for occlusal kinematics in conodonts', Lethaia, vol. 47, no. 4, pp. 547-555.

Martínez-Pérez, C., Rayfield, E. J., Botella, H. and Donoghue, P. C. (2016) 'Translating taxonomy into the evolution of conodont feeding ecology', Geology, vol. 44, no. 4, pp. 247-250. Martínez-Pérez, C., Rayfield, E. J., Purnell, M. A. and Donoghue, P. C. J. (2014) 'Finite element, occlusal, microwear and microstructural analyses indicate that conodont microstructure is adapted to dental function', Palaeontology, vol. 5, pp. 1059-1066.

Peer] reviewing PDF | (2021:07:63847:2:0:NEW 20 Oct 2021) 
690 McFarlane, G., Guatelli-Steinberg, D., Loch, C., White, S., Bayle, P., Floyd, B., Pitfield, R. and

691 Mahoney, P. (2021) 'An inconstant biorhythm: The changing pace of Retzius periodicity in

692 human permanent teeth', American Journal of Physical Anthropology. DOI: 10.1002/ajpa.24206

693 Mcllroy, D. and Szaniawski, H. (2000) 'A lower Cambrian protoconodont apparatus from the

694 Placentian of southeastern Newfoundland', Lethaia, vol. 33, pp. 92-102.

695 Mellgren, J. S. and Eriksson, M. E. (2006) 'A model of reconstruction for the oral apparatus of

696 the Ordovician conodont genus Protopanderodus Lindström, 1971', Transactions of the Royal

697 Society of Edinburgh: Earth Sciences, vol. 97, no. 2, pp. 97-112.

698 Miller, J. F. (1980) 'Some Upper Cambrian and Lower Ordovician Conodonts', The University of

699 Kansas Paleontological Contributions, vol. 99.

700 Miller, J.F. (1984) 'Cambrian and earliest Ordovician conodont evolution, biofacies and

701 provincialism', In: Clark, D.L. (1984) Conodont Biofacies and Provincialism, Geological Society

702 of America Special Paper 196, pp.43-68.

703 Müller, K. J. and Hinz-Schallreuter, I. (1998) 'Internal structure of Cambrian Conodonts', Journal

704 of Palaeontology, vol. 72, no. 1, pp. 91-112.

705 Müller, K. J. and Nogami, Y. a. (1971) 'Über den Feinbau der Conodonten', Serioes of Geology 706 and Mineralogy, vol. 38, no. 1, pp. 1-87.

707 Murdock, D. J. E., Dong, X.-P., Repetski, J. E., Marone, F., Stampanoni, M. and Donoghue, P.

708 C. J. (2013) 'The origin of conodonts and of vertebrate mineralized skeletons', Nature, vol. 502,

709 no. 7472 , pp. 546-549.

710 Murdock, D. J. E. and Donoghue, P. C. J. (2011) 'Evolutionary origins of animal skeletal

711 biomineralization', Cells Tissues Organs, vol. 194, 2-4, pp. 98-102.

712 Murdock, D. J. E., Rayfield, E. J. and Donoghue, P. C. J. (2014) 'Functional adaptation

713 underpinned the evolutionary assembly of the earliest vertebrate skeleton', Evolution \&

714 Development, vol. 16, no. 6, pp. 354-361.

715 Murdock, D. J. E., Sansom, I. J. and Donoghue, P. C. J. (2013) 'Cutting the first 'teeth': a new

716 approach to functional analysis of conodont elements', Proceedings of the Royal Society:

717 Biological Sciences, vol. 280, no. 1768, 20131524.

718 Murdock, D. J. E. and Smith, M. P. (2021b) 'Data from: Panderodus from the Waukesha

719 lagerstätte of Wisconsin, USA: the anatomy of primitive macrophagous vertebrate predators',

720 Dryad, Dataset. Available at https://doi.org/10.5061/dryad.0p2ngf20z.

721 Murdock, D. J. E. and Smith, M. P. (2021a) 'Panderodus from the Waukesha Lagerstätte of

722 Wisconsin, USA: a primitive macrophagous vertebrate predator', Papers in Palaeontology,

723 pp. 1-17.

724 Nazarova, V. M. and Kononova, L. I. (2020) 'Paleopathology: Occurrence of anomalies in the

725 elements of Devonian conodonts', Paleontological Journal, vol. 54, no. 7, pp. 743-756.

726 Nicoll, R. S. and Rexroad, C. B. (1987) 'Re-examination of Silurian conodont clusters from

727 northern Indiana', Palaeobiology of conodonts, pp. 49-61.

728 Owocki, K. and Madzia, D. (2020) 'Predatory behaviour in mosasaurid squamates inferred from

729 tooth microstructure and mineralogy', Cretaceous Research, 104430.

730 Peek, S. and Clementz, M. T. (2012) 'Sr/Ca and Ba/Ca variations in environmental and

731 biological sources: A survey of marine and terrestrial systems', Geochimica et Cosmochimica

732 Acta, vol. 95, pp. 36-52. 
733 Petryshen, W., Henderson, C. M., Baets, K. de and Jarochowska, E. (2020) 'Evidence of 734 parallel evolution in the dental elements of Sweetognathus conodonts', Proceedings of the 735 Royal Society: Biological Sciences, vol. 287, no. 1939, 20201922.

736 Pietzner, H., Vahl, J., Werner, H. and Ziegler, W. (1968) 'Zur chemischen Zusammensetzung 737 und Mikromorphologie der Conodonten', Palaeontographica Abteilung A: Paläozoologie -

738 Stratigraphie, 4-6, pp. 115-152.

739 Purnell, M. A. (1993) 'Feeding mechanisms in conodonts and the function of the earliest 740 vertebrate hard tissues', Geology, vol. 21, pp. 375-377.

741 Purnell, M. A. (1995) 'Microwear in conodont elements and macrophagy in the fist vertebrates',

742 Nature, vol. 374, pp. 798-800.

743 Purnell, M. A. (2001) 'Feeding in Conodonts and other Early Vertebrates', Palaeoecology,

744 no. 4.1.9, pp. 401-404.

745 Purnell, M. A. and Donoghue, P. C. J. (1997) 'Architecture and functional morphology of the 746 skeletal apparatus of ozarkodinid conodonts', Philosophical Transactions of the Royal Society 747 Biological Sciences, vol. 352, pp. 1545-1564.

748 Rayfield, E. J. (2007) 'Finite Element Analysis and understanding the biomechanics and 749 evolution of living and fossil organisms', Annual Review of Earth and Planetary Sciences, 750 vol. 35 , no. 1 , pp. 541-576.

751 Reid, D. J. and Dean, M. C. (2000) 'Brief communication: The timing of linear Hypoplasias on 752 human anterior teeth', American journal of physical anthropology, vol. 113, no. 1, pp. 135-139. 753 Reynard, B. and Balter, V. (2014) 'Trace elements and their isotopes in bones and teeth: diet, 754 environments, diagenesis, and dating of archeological and paleontological samples', 755 Palaeogeography, Palaeoclimatology, Palaeoecology, vol. 416, pp. 4-16.

756 Rhodes, F. and Phillips, R. (1953) 'The zoological affinities of the conodonts', Biological

757 Reviews, vol. 29, no. 4, pp. 419-452.

758 Ricklefs, R. E. (2003) 'Is rate of ontogenetic growth constrained by resource supply or tissue 759 growth potential? A comment on West et al.'s model', Functional Ecology, vol. 17, pp. 384-393.

760 Ritz, C., Baty, F., Streibig, J. C. and Gerhard, D. (2015) 'Dose-Response Analysis using R', 761 PLoS one, vol. 10, no. 12.

762 Sansom, I. J., Armstrong, H. A. and Smith, M. P. (1994) 'The apparatus architecture of

763 Panderodus and its implications for coniform conodont classification', Palaeontology, vol. 37, 764 no. 4, pp. 781-799.

765 Sebens, K. P. (1982) 'The limits to indeterminate growth: an optimal size model applied o 766 passive suspension feeders', Ecology, vol. 63, no. 1, pp. 209-222.

767 Sebens, K. P. (1987) 'The ecology of indeterminate growth in animals', Annual Review of 768 Ecology, Evolution and Systematics, vol. 18, pp. 371-407.

769 Shirley, B., Bestmann, M. and Jarochowska, E. (2020) 'The cono-dos and cono-dont's of 770 phosphatic microfossil preparation and microanalysis', Micron, vol. 138, 102924.

771 Shirley, B., Grohganz, M., Bestmann, M. and Jarochowska, E. (2018) 'Wear, tear and 772 systematic repair: testing models of growth dynamics in conodonts with high-resolution 773 imaging', Proceedings of the Royal Society: Biological Sciences, vol. 285, 20181614.

774 Sillen, A. (1993) 'Strontium-calcium ratios ( $\mathrm{Sr} / \mathrm{Ca}$ ) of Australopithecus robustus and associated

775 fauna from Swartkrans', Journal of human evolution, vol. 23, pp. 495-516. 
776

777

778

779

780

781

782

783

784

785

786

787

788

789

790

791

792

793

794

795

796

797

798

799

800

801

802

803

804

805

806

807

808

809

810

811

812

813

814
Sillen, A. and Lee-Thorp, J. (1994) 'Trace element and isotopic aspects of predator-prey relationships in terrestrial foodwebs', Palaeogeography, Palaeoclimatology, Palaeoecology, vol. 107, pp. 243-255.

Smith M.P., Briggs, D.E.G. and Aldridge, R.J. (1987) 'A conodont animal from the Lower Silurian of Wisconsin, U.S.A., and the apparatus architecture of panderodontid conodonts', In Aldridge, R.J. (ed.) Palaeobiology of Conodonts. Ellis Horwood, Chichester, pp. 91-104. Sponheimer, M., Ruiter, D. de, Lee-Thorp, J. and Späth, A. (2005) 'Sr/Ca and early hominin diets revisited: new data from modern and fossil tooth enamel', Journal of Human Evolution, vol. 48, pp. 147-156.

Stamps, J. A., Mangel, M. and Phillips, J. A. (1998) 'A new look at relationships between size at maturity and asymptotic size', The American Naturalist, vol. 152, no. 3, pp. 470-479.

Sweet, W. C. and Donoghue, P. C. J. (2001) 'Conodonts: past, present, future', Journal of Palaeontology, vol. 75, no. 6, pp. 1174-1184.

Szaniawski, H. (2009) 'The earliest known venomous animals recognized among conodonts', Acta Palaeontologica Polonica, vol. 54, no. 4, pp. 669-676.

Szaniawski, H. and Bengston, S. (1998) 'Late Cambrian euconodonts from Sweden', Palaeontologica Polonica, vol. 58, pp. 7-29.

Trotter Julie A. and Eggins, S. M. (2006) 'Chemical systematics of conodont apatite determined by laser ablation ICPMS', Chemical Geology, vol. 233, 3-4, pp. 196-216.

Trotter Julie A., Fitz Gerald, J. D., Kokkonen, H. and Barnes, C. R. (2007) 'New insights into the ultrastructure, permeability, and integrity of conodont apatite determined by transmission electron microscopy', Lethaia, vol. 40, no. 2, pp. 97-110.

Wright, J., Seymour, R. S. and Shaw, H. F. (1984) 'REE and Nd isotopes in conodont apatite: Variations with geological age and depositional environment', Geological Society of America, Special Paper 196, pp. 325-340.

Zhan, S., Aldridge, R. J. and Donoghue, P. C. J. (1997) 'An Early Triassic conodont with periodic growth?', Journal of Micropalaeontology, vol. 16, pp. 65-72.

Zhu, P., Zhang, K., Wang, Z., Liu, Y., Liu, X., Wu, Z., McDonald, S. A., Marone, F., Stampanoi, M. (2010) 'Low-dose, simple, and fast grating-based X-ray phase-contrast imaging',

Proceedings of the National Academy of Sciences of the United States of America, vol. 107, no. 31, pp. 13576-13581.

Zhuravlev, A. V. and Shevchuck, S. S. (2017) 'Strontium distribution in Upper Devonian conodont elements: A palaeobiological proxy', Rivista Italiana di Paleontologica e Stratigrafia, vol. 123, no. 2, pp. 203-210.

Žigaitè, Ž., Qvarnström, M., Bancroft, A., Pérez-Huerta, A., Blom, H. and Ahlberg, P. E. (2020) 'Trace and rare earth element compositions of Silurian conodonts from the Vesiku Bone Bed: Histological and palaeoenvironmental implications', Palaeogeography, Palaeoclimatology, Palaeoecology, vol. 549, no. 109449. 


\section{Table $\mathbf{1}$ (on next page)}

Growth models fitted to cumulative growth curves of both specimens.

[p]Models fitted to cumulative growth curves obtained from BSE images across sections through Panderodus equicostatus (25 degrees of freedom) and Proconodontus muelleri (56 degrees of freedom). All model parameter estimates were significant at alpha $=0.001$. 
1 Table 1.

2

\begin{tabular}{|l|l|l|l|}
\hline Taxon & Model descriptor & Linear growth model & $\begin{array}{l}\text { Allometric growth } \\
\text { model }\end{array}$ \\
\hline $\begin{array}{l}\text { Panderodus } \\
\text { equicostatus }\end{array}$ & Formula & $y=0.3941 x+0.4725$ & $y=0.6092 x^{0.8749}$ \\
\hline & Residual standard error & 0.2498 & 0.1554453 \\
\hline & AIC & 5.640348 & -19.97418 \\
\hline $\begin{array}{l}\text { Proconodontus } \\
\text { muelleri }\end{array}$ & Formula & $y=0.5472 x+0.8114$ & $y=0.7891 x^{0.9119}$ \\
\hline & Residual standard error & 0.5721 & 0.3597 \\
\hline & AIC & 103.7894 & 49.95944 \\
\hline
\end{tabular}

3 


\section{Figure 1}

Overview about the specimens used (Light microscope and SEM image, as well as SRXTM scan).

A-B. Light microscope image (A) and SEM-image (B) of Pa. equicostatus; C-F. Light microscope image (C), SEM-image (D) and SRXTM scans (E-F) of Pr. muelleri. Scale bars equal $200 \mu \mathrm{m}(\mathrm{A}-\mathrm{D})$ and $100 \mu \mathrm{m}(\mathrm{E}-\mathrm{F})$.

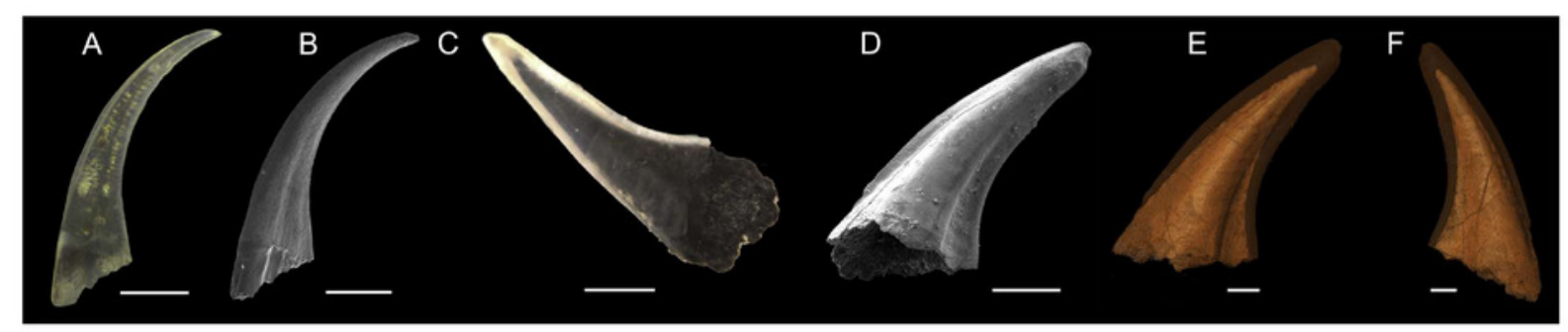




\section{Figure 2}

BSE image of Proconodontus muelleri outlining the transects along which Sr and Ca contents were measured.

Composite BSE image of the polished aequaliform element of Pr. muelleri outlining three transects (1-3) along which Sr and Ca contents were measured. Changes in the Sr/Ca ratio with growth are expressed as the number of counts (cts). The red line marks the transect along which the lamellae were counted (for close-up see Fig.6A). Scale bar equals $200 \mu \mathrm{m}$.






\section{Figure 3}

BSE image of Panderodus equicostatus outlining the transects along which $\mathrm{Sr}$ and $\mathrm{Ca}$ contents were measured.

Composite BSE image of the polished truncatiform element of $\mathrm{Pa}$. equicostatus outlining six transects (1-6) along which Sr and Ca contents were measured. Changes in the Sr/Ca ratio though ontogeny are expressed as the number of counts (cts). Transect six was excluded from the analysis since most of it lied within the basal body). The red line marks the transect along which the lamellae were counted (for close-up see Fig. 7A). Scale bar equals $200 \mu \mathrm{m}$.




Figure 4

Relative concentrations of $\mathrm{Sr}$ and Ca per transects in the crown tissue of Panderodus equicostatus and Proconodontus muelleri.

Relative concentrations of Sr and Ca per transect (247 points per transect) in the crown tissue of Pa. equicostatus (A-B) and Pr. muelleri (C-D).



\section{Figure 5}

Linear mixed effect model fitted to Sr/Ca ratio across the crown tissue of Panderodus equicostatus and Proconodontus muelleri.

Linear mixed effect model fitted to Sr/Ca ratios across transects 1-3 through crown tissue of Pr. muelleri and transects 1-5 through the crown tissue of Pa. equicostatus from the inner to outer side of the element. The length of each transect was scaled to the $[0,1]$ interval.
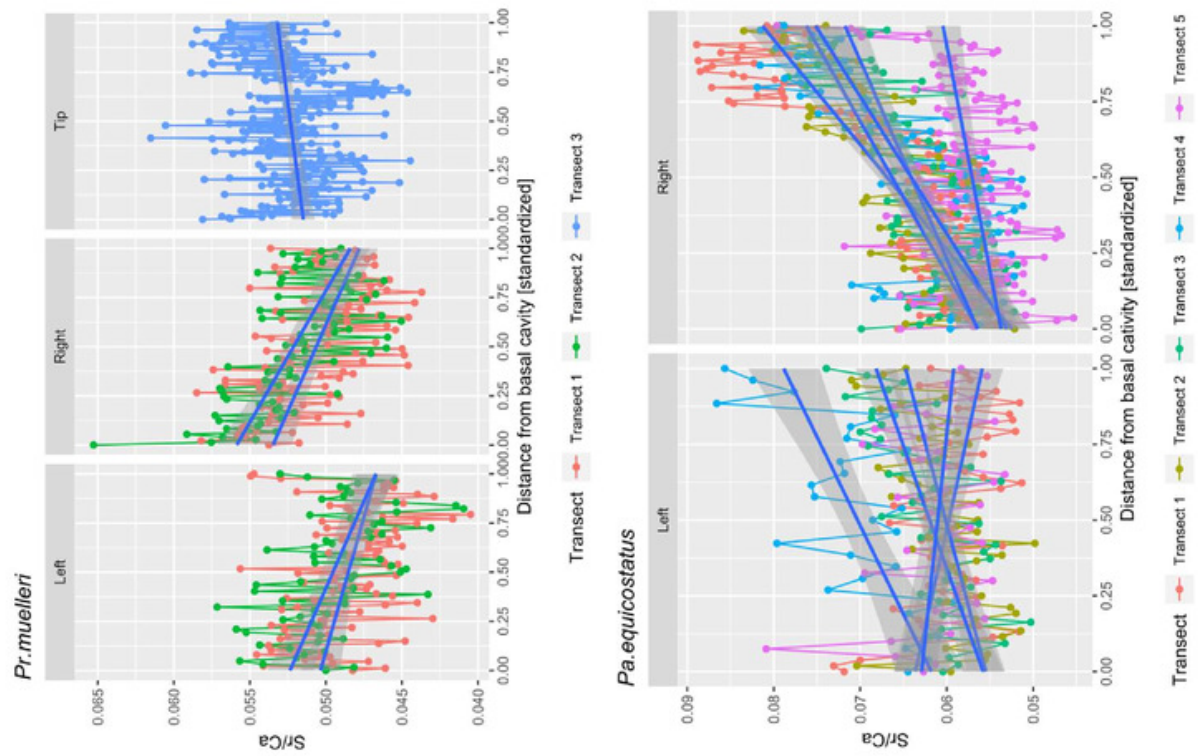


\section{Figure 6}

Reconstruction of the growth dynamics of Proconodontus muelleri.

Reconstruction of growth dynamics of Pr. muelleri obtained from the high-resolution BSE image (A). A. Transect through lamellar tissue on the outer side of the element along which lamellae were counted from the inner side towards the outer edge; B. Growth curve with power law function fitted; $C$. Thickness $[\mu \mathrm{m}]$ and number of counted growth increments; Deposition of 48 increments with mean width of $0.47 \mu \mathrm{m}$ in six bundles of seven-nine increments each. 


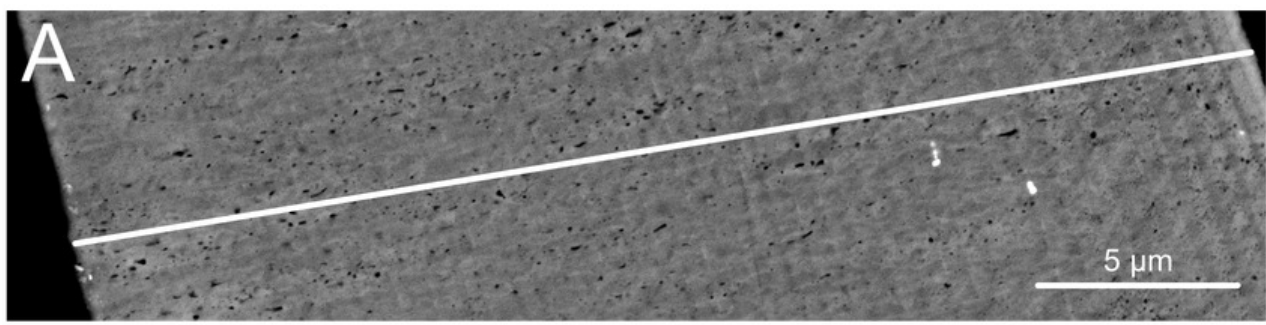

B

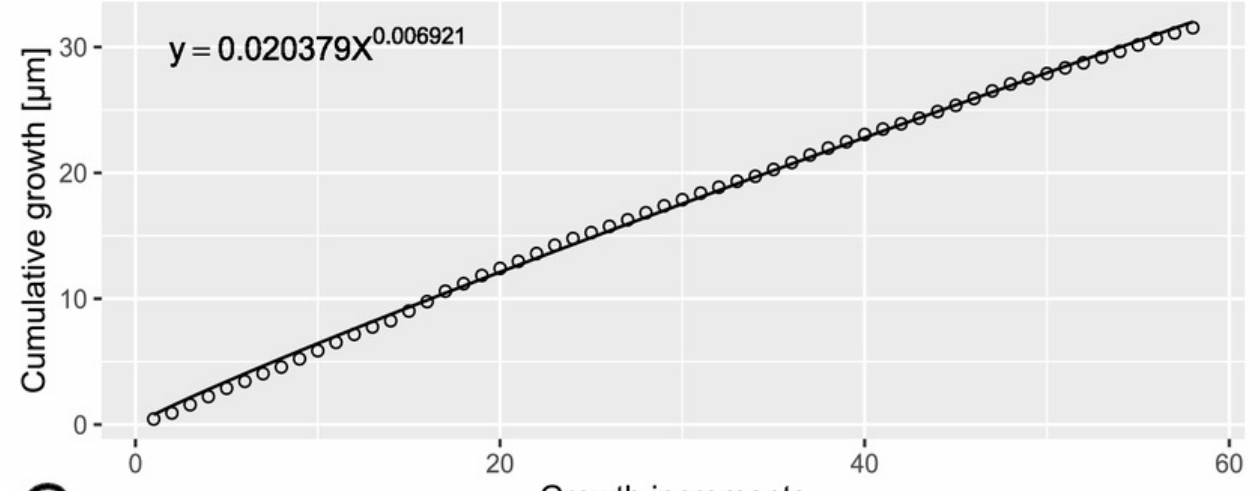

C

Growth increments

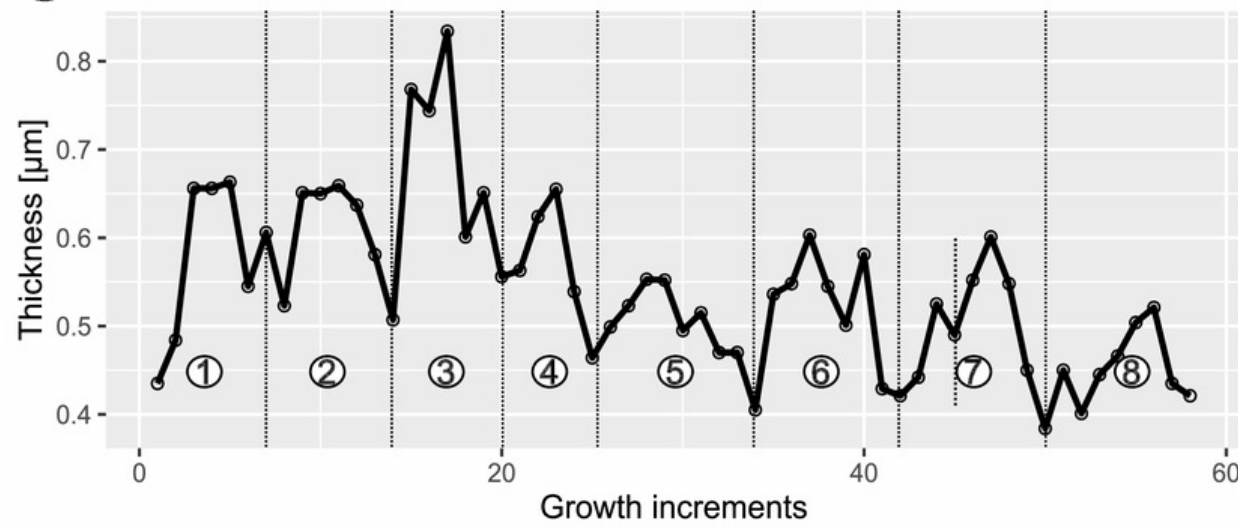




\section{Figure 7}

Reconstruction of the growth dynamics of Panderodus equicostatus.

Reconstruction of growth dynamics of $P a$. equicostatus obtained from high-resolution BSE image (A). A. Transect through lamellar tissue on outer side of the element along which lamellae were counted from the inner side towards the outer edge (note: lamellae adjacent to the basal body were not clearly detectable); B. Growth curve with power law function fitted; C. Thickness [ $\mu \mathrm{m}]$ and number of counted growth increments; Deposition of 22 increments with mean width of $0.37 \mu \mathrm{m}$ in six bundles with 4-7 increments each. 


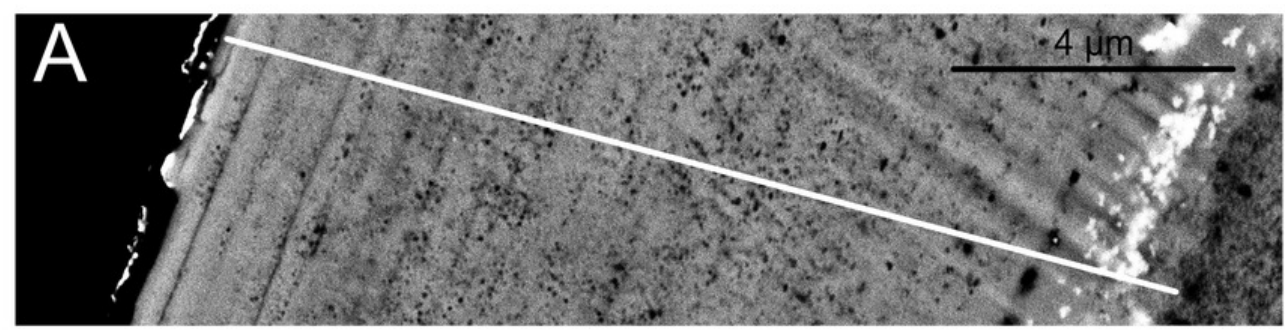

\section{B}
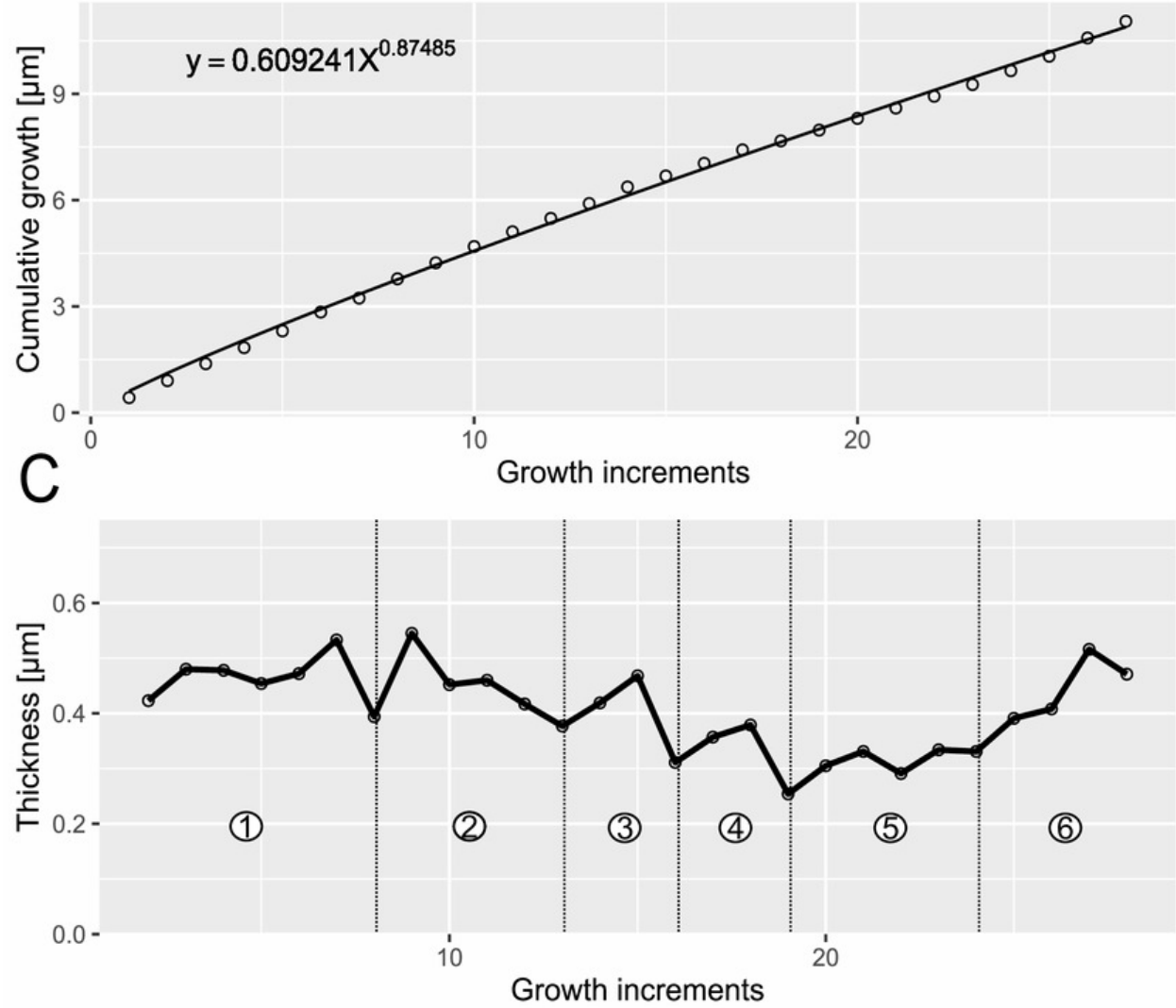


\section{Figure 8}

BSE image of the tip of Proconodontus muelleri.

High-resolution BSE image of the tip area of Pr. muelleri. Sequence of eight truncated, irregular surfaces (scale bar $35 \mu \mathrm{m}$ ).

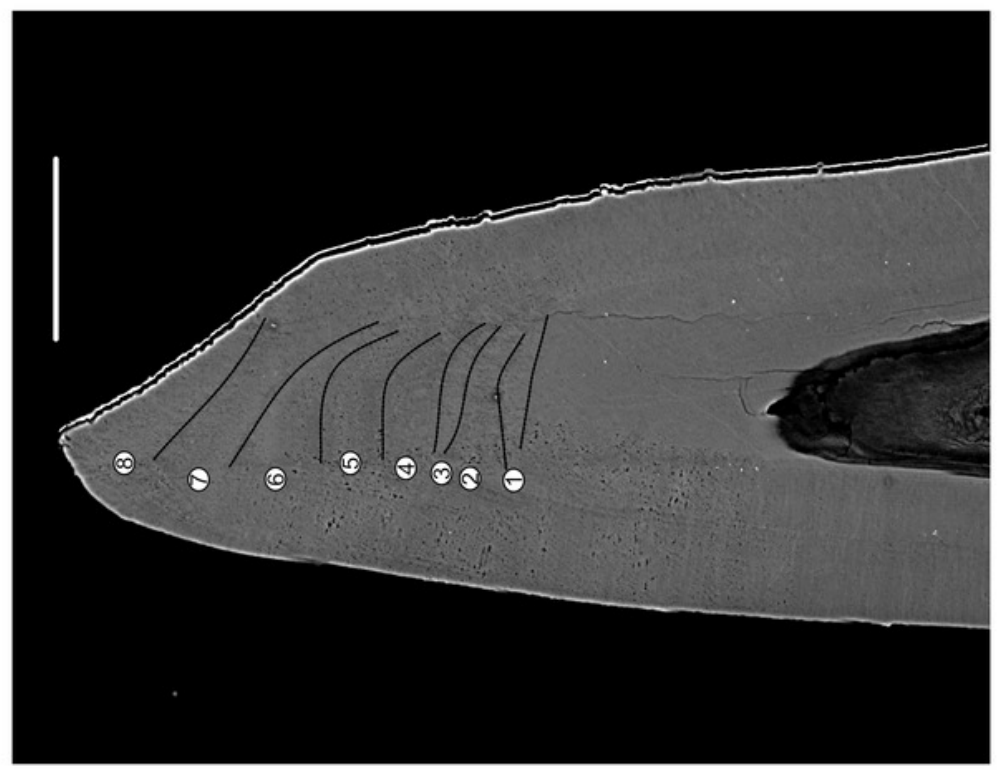

